\title{
Editorial Introduction: The Beat of a Different Drum-Voluntary Associations as an Alternative and Neglected Voluntary Sector Paradigm
}

In his latest major contribution to the study of voluntary associations, David Horton Smith makes a friendly reference to a book I published recently. In Rediscovering voluntary action: The beat of a different drum (Palgrave Macmillan, 2013), I challenged the conventional view of the nature of the UK's voluntary sector and, by implication, of the nonprofit sector in the Us and elsewhere. I argued that we needed a fresh approach and "the development of an alternative paradigm."

During the forty-five-plus years of my involvement in the practice and study of voluntary action, I have witnessed a growing concentration of interest in a narrow spectrum of voluntary agencies (nearly always operated mainly by paid staff) to the exclusion of the wider number of groups and organizations, mainly voluntary associations. Such membership associations, most of them local in scope and operated solely by volunteers, have most clearly exemplified the distinctive characteristics of, and the contribution to society made by, the voluntary sector. For many decades, the scholarly and also general public view of the voluntary sector has been dominated by the purposes and methods of the comparatively small number of professionally staffed, bureaucratically organized, and managerially focused agencies that have increasingly reflected the concerns of government and also have adopted the methods of the private for-profit sector. As a result, most of the values, aims, and practices of the much greater number of the voluntary associations (together with some ambiguous voluntary agencies that combine the world of the association with the workings of bureaucracies) have been largely written out of the story.

Rediscovering voluntary action argues for "a realignment of our map of the voluntary sector or ... a shift in the sector's centre of gravity." Instead of concentrating on the largest and most bureaucratic forms of voluntary organization, my "alternative paradigm focuses attention on the organisational forms that exhibit the organisational features that define the distinctive nature of voluntary action." The book also sets out a research agenda that will "concentrate on the activities and behaviour of unmanaged volunteers involved in nonbureaucratic organisational settings." The aims of such an agenda would be to identify the ways in which voluntary action is different from other forms of collective activity and how non-bureaucratic voluntary groups are organised and managed in special ways. 
These aspirations echo some of the concerns that have shaped the long and fertile intellectual journey undertaken by David Horton Smith over more than fifty years, during which he has published a series of influential articles and several major books promoting voluntary action and explaining the importance within it of the role of membership associations. He has developed two striking metaphors that characterized associations as the dark matter of the voluntary nonprofit sector and has explained the lack of scholarly interest in them by reference to the prevalence of flat earth maps of the sector's territory. His magisterial survey of Grassroots associations (SAGE, 2000) provided a comprehensive account of the behavior of these organizations and the recent publication of The Palgrave handbook of volunteering, civic participation, and nonprofit associations (Palgrave Macmillan, 2016), which he co-edited with Bob Stebbins and Jurgen Grotz, has provided an encyclopedic account of voluntary action on a global scale, especially volunteering and membership associations.

And not least of his contributions to the study of voluntary action has been the development of an emerging academic discipline that reflects his wideranging concerns (and has been enshrined in the title of this journal). I have to admit that I find the name he has chosen-Voluntaristics - far from euphonious, but I have no concerns about the utility of the term that embraces a wide range of "individual and collective human phenomena ... that involve relatively non-coerced, free will decisions and behaviors" and which, as well as broadening the focus of these activities, distances them from what now increasingly seems to be the discredited, or at least often ignored, concept of voluntary action.

David Horton Smith's latest contribution to the study of voluntaristics in this issue of Voluntaristics Review, Vol. 2, No. 5-6, is typically ambitious in its scope. It seeks to demonstrate just how important membership associations are to the historical development of human society and sets out his stall in a broad-brush approach and painting a broad canvas. In the first place, he draws on evidence from an historical account that goes back for 300 years. Secondly, he reviews experience collected from a range of geographical sources; while much of his evidence is based on the us and Western Europe, he also presents significant examples of experience drawn from Latin America, Asia, and Africa. The third dimension of the scope of his interests sets out the variety of issues or topics covered by his review, including some general features of voluntary associations that contribute to their important historical impacts since the Industrial Revolution.

Much of the material he covers could be described in broad terms as political: he reviews the impact on the historical development of society from the perspective of associations that promote social change through various kinds 
of political activity. These have been involved in social movements and social movement organizations; associations that promote revolutions, guerrilla activities, and civil wars; associations that promote democracy; underground resistance movements and other deviant groups; single-issue interest and pressure groups; and the role of political parties as membership associations. While many of these organizations may individually have limited impact on social and political change, their cumulative or aggregated effects are, as Smith argues, profound. He also calls to mind other kinds of membership association which play their parts in our wider society-those who organize around shared religious beliefs; those which support businesses, farmers, factory workers, or specific professions; and a variety of other kinds of purposes for which associations organize and provide support.

The variety of associational forms brought together in this article and the range of literature on which it is based inevitably produce an account which is wide-ranging but can be criticized as lacking detail. Arguably, each one of Smith's types of association and its impact on society requires not just an article but quite possibly a book to support his overall contention that they demonstrate just how important membership associations are to the historical development of human society (although he cites many such relevant books in each section). Such criticism would be to mistake what I would see as the main purpose of the current article. What Smith has done-as he has often done before-is to shine the strong beam of his wide-angled searchlight on his perceptions about the importance of membership associations in such a way that no-one can ignore what he has to say about them. Clearly, such associations have had major impacts on societies and history in the past two and a half centuries-likely more impact than most academics, let alone the general public, have understood or recognized.

\section{Colin Rochester}

Visiting Senior Fellow

The London School of Economics and Political Science, London, UK 